Part of Journal of Research of the National Bureau of Standards, Volume 21, August 1938

\title{
STUDIES OF HEAT OF SOLUTION OF CALCIUM AND MAGNESIUM OXIDES AND HYDROXIDES
}

\author{
By Kenneth Taylor and Lansing S. Wells
}

\section{ABSTRACT}

The heat evolved in the solution of $\mathrm{MgO}$ in hydrochloric acid was found to decrease as the temperature at which the $\mathrm{MgO}$ was prepared was increased. This is shown in the following equations, where the values given are those of $\Delta H$, the increment in the heat content. The negative sign, therefore, indicates the evolution of heat.

$\mathrm{MgO}$ (c) [prepared by dehydrating $\mathrm{Mg}(\mathrm{OH})_{2}$ for 2.5 hours at $450^{\circ} \mathrm{C}$ ] $+17,630$ $\mathrm{g}$ of $2.085 \mathrm{M} \mathrm{HCl}=$ solution; $\Delta H_{288.1^{\circ} \mathrm{K}}=-36.67 \pm 0.07 \mathrm{kcal}$, and

$\mathrm{MgO}$ (c) [prepared by dehydrating $\mathrm{Mg}(\mathrm{OH})_{2}$ for 2.5 hours at $1,425^{\circ} \mathrm{C}$ ] $+17,630$ $\mathrm{g}$ of $2.085 \mathrm{M} \mathrm{HCl}=$ solution; $\Delta \mathrm{H}_{298.1^{\circ} \mathrm{K}}=-35.72 \pm 0.03 \mathrm{kcal}$.

The decrease in the heat evolved is ascribed mainly to an increase in the particle size of the $\mathrm{MgO}$ as the temperature of ignition was increased. Since X-ray diffraction patterns were similar there appeared to be no change in crystalline form. The increase in particle size was indicated by a decrease in the rate of solution in the calorimeter and was verified by sedimentation experiments. Heat values have also been obtained for the solution of $\mathrm{Mg}(\mathrm{OH})_{2}, \mathrm{CaO}$, and $\mathrm{Ca}(\mathrm{OH})_{2}$ in hydrochloric acid. Heat of hydration of $\mathrm{MgO}$ and $\mathrm{CaO}$ was calculated from heat-of-solution data. The heat of hydration of $\mathrm{MgO}$ to $\mathrm{Mg}(\mathrm{OH})_{2}$ depends on the characteristic properties of both the $\mathrm{MgO}$ and $\mathrm{Mg}(\mathrm{OH})_{2}$. Heat of hydration of $\mathrm{CaO}$ to $\mathrm{Ca}(\mathrm{OH})_{2}$ was also determined by direct hydration of $\mathrm{CaO}$ in a solution saturated with respect to $\mathrm{Ca}(\mathrm{OH})_{2}$.

\section{CONTENTS}

Page

I. Introduction _.

II. General procedure

III. Apparatus and materials.

IV. Effect of the temperature of ignition on the heat of solution of $\mathrm{MgO}$ in hydrochloric acid

1. Experimental_

2. Corrections

V. Heat of solution of $\mathrm{Mg}(\mathrm{OH})_{2}$ in hydrochloric acid

VI. Heats of solution of $\mathrm{CaO}$ and $\mathrm{Ca}(\mathrm{OH})_{2}$ in hydrochloric acid $\ldots \ldots . . .144$

VII. Heats of hydration of $\mathrm{MgO}$ and $\mathrm{CaO}$

VIII. Summary _.........

IX. References $\ldots$

\section{INTRODUCTION}

In a recent investigation at the National Bureau of Standards of the hydration of magnesia in dolomitic limes and putties [1] ${ }^{1}$ it was

${ }_{1}^{1}$ Figures in brackets here and elsewhere throughout the text indicate the literature references at the end of this paper. 
necessary to determine the heats of solution of $\mathrm{MgO}, \mathrm{Mg}(\mathrm{OH})_{2}$, $\mathrm{CaO}$, and $\mathrm{Ca}(\mathrm{OH})_{2}$ in hydrochloric acid. Since the values were to be used only for the purpose of ascertaining the percentage of $\mathrm{MgO}$ in dolomitic hydrated limes and putties, several minor corrections which were not significant in that determination were omitted. Furthermore, the data in that paper pertain only to calcium oxide and magnesium oxide ignited at temperatures roughly approximating those at which dolomitic limes are burned in practice. It has been found in this laboratory that the heat of solution of magnesium oxide depends appreciably on the temperature of ignition prior to its solution. This paper describes the variation in the heat of solution of $\mathrm{MgO}$ and includes data on the heats of solution of $\mathrm{Mg}(\mathrm{OH})_{2}, \mathrm{CaO}$, and $\mathrm{Ca}(\mathrm{OH})_{2}$ in addition to those given previously [1].

\section{GENERAL PROCEDURE}

In the preparation of $\mathrm{MgO}$ and $\mathrm{CaO}$ for the determination of heats of solution, samples of $\mathrm{Mg}(\mathrm{OH})_{2}$ and $\mathrm{CaCO}_{3}$ were ignited, cooled to room temperature in a desiccator, and immediately weighed and sealed in the sample container of the calorimeter. The MgO, when not sealed, was found to take up moisture rapidly for 10 or 15 minutes after its removal from the desiccator. Since $\mathrm{CaO}$ also increases in weight upon exposure to air under ordinary conditions, it was desirable to make weighings of these materials as rapidly as possible. For this reason no attempt was made to take samples of exactly the same weight although equal weights of acid solution were used in the different experiments. Such a procedure produces differences in the concentrations of the constituents of the final calorimetric solutions. Corrections have been made for these variations, although they are relatively small in the experiments described in this paper.

Heat-capacity measurements were made by adding definite amounts of electrical energy to the calorimeter plus the initial hydrochloric acid solution rather than to the calorimeter plus the final more complex solutions. The heat capacities of the samples $[4,5]$ were therefore added to that of the calorimeter containing the initial acid solution, and the heat-of-solution values corrected to a final temperature of $25^{\circ} \mathrm{C}$. This procedure gives the heat of the isothermal reaction at $25^{\circ} \mathrm{C}$.

The "energy equivalent error" [18], $a$, (three times the "probable error") of the heat-capacity measurements of the calorimeter was calculated by the formula

$$
a= \pm(100) \frac{2 \sqrt{\Sigma \Delta^{2} / m(m-1)}}{(\text { value of energy equivalent })} \text { percent }
$$

where $\Sigma \Delta^{2}$ is the sum of the squares of the $m$ deviations from the arithmetical average of the experimental values.

Likewise, the "reaction error", $b$, was calculated by the formula

$$
b= \pm(100) \frac{2 \sqrt{\Sigma \Delta^{2} / n(n-1)}}{\text { (value of reaction energy) }} \text { percent, }
$$

where $n$ is the number of determinations of the heat of solution.

The final assigned "precision error" of the average value for the heat of solution is

$$
\text { "precision error" }= \pm \sqrt{a^{2}+b^{2}} \text { percent. }
$$


The last equation was also used to calculate the error of the sum or difference of two heats of solution $A$ and $B$ affected with errors $a$ and $b$, but the errors in this case must be expressed in calories and not in percent. The final change back to percent was made after the addition or subtraction was completed and the magnitudes of both the error and desired quantity were known.

The unit of energy employed in this work is the National Bureau of Standards International Joule, and conversion to a defined or conventional calorie is made by using the factor $1 / 4.1833$. See reference [18] for further information on this point.

\section{APPARATUS AND MATERIALS}

The calorimeter used in this work has been adequately described in previous publications [2]. The temperature of the water surrounding the outside jacket of the calorimeter was maintained at $25 \pm 0.005^{\circ} \mathrm{C}$.

The hydrochloric acid solutions were prepared from concentrated acid of analytical reagent quality and distilled water.

Two samples of magnesium hydroxide were used. The first was naturally occurring brucite which was completely soluble in hydrochloric acid, free of silica, and contained only traces of calcium, iron, and aluminum oxides. The second sample was prepared from magnesium oxide of analytical reagent quality. Before being used, the oxide was extracted with water to remove any water-soluble substance with which it might be contaminated. An analysis then showed that it was completely soluble in hydrochloric acid, free of chlorides and sulfates, and contained only traces of iron and aluminum oxides. In the preparation of magnesium hydroxide, this oxide was ignited in a muffle furnace for several hours at $850^{\circ} \mathrm{C}$, hydrated with steam in an autoclave for 2 hours at a pressure of $120 \mathrm{lb} / \mathrm{in}^{2}$, and then oven-dried for 1 hour at $105^{\circ} \mathrm{C}$.

The magnesium oxide used in all determinations of heat of solution was obtained by dehydrating the above prepared magnesium hydroxide at the desired temperature.

Calcium carbonate of analytical reagent quality was used in the preparation of calcium oxide and calcium hydroxide. The carbonate was completely soluble in hydrochloric acid, free of chlorides, sulfates, and silicates, and contained only traces of iron and aluminum oxides. Calcium oxide was obtained by igniting the carbonate for about 4 hours over a Meeker burner just prior to each determination of heat of solution. The ignition temperature was $1,050^{\circ}$ to $1,100^{\circ} \mathrm{C}$. In the preparation of calcium hydroxide, the carbonate was ignited in a muffle furnace for several hours at $950^{\circ} \mathrm{C}$ and then hydrated and dried as in the preparation of magnesium hydroxide.

\section{EFFECT OF THE TEMPERATURE OF IGNITION ON THE HEAT OF SOLU'TION OF MgO IN HYDROCHLORIC ACID}

\section{EXPERIMENTAL}

Experimental evidence indicates that in some instances the heat of solution of a material is markedly affected by the manner in which it is prepared. Thus, Fricke, Schnobel, and Beck [3], by varying the method of preparation of $\mathrm{Mg}(\mathrm{OH})_{2}$, obtained differences in its heat 
of solution in $3.75 \mathrm{~N} \mathrm{HCl}$ of as much as $850 \mathrm{cal}$ per mole. Newman and Wells [2] have reported differences in the heat of solution (in $2.09 \mathrm{M} \mathrm{HCl}$ ) of the stable form of $\mathrm{CaSO}_{4}$ prepared by dehydrating $\mathrm{CaSO}_{4} \cdot 2 \mathrm{H}_{2} \mathrm{O}$ at various temperatures, and for various periods of time at the same temperature. These differences have been attributed to differences in surface rather than to any fundamental change in the internal structure of the crystals.

It is well known that the apparent density of $\mathrm{MgO}$ increases appreciably upon ignition at increasingly higher temperatures. Therefore, it seemed reasonable that its heat of solution might be affected by the temperature at which it had been ignited previous to a determination. This was further suggested by the diserepancy in the heat of hydration of $\mathrm{MgO}$ prepared by dehydrating $\mathrm{Mg}(\mathrm{OH})_{2}$ at $1,050^{\circ}$ to $1,100^{\circ} \mathrm{C}$, as determined in this laboratory [1], and that of $\mathrm{MgO}$ pre-

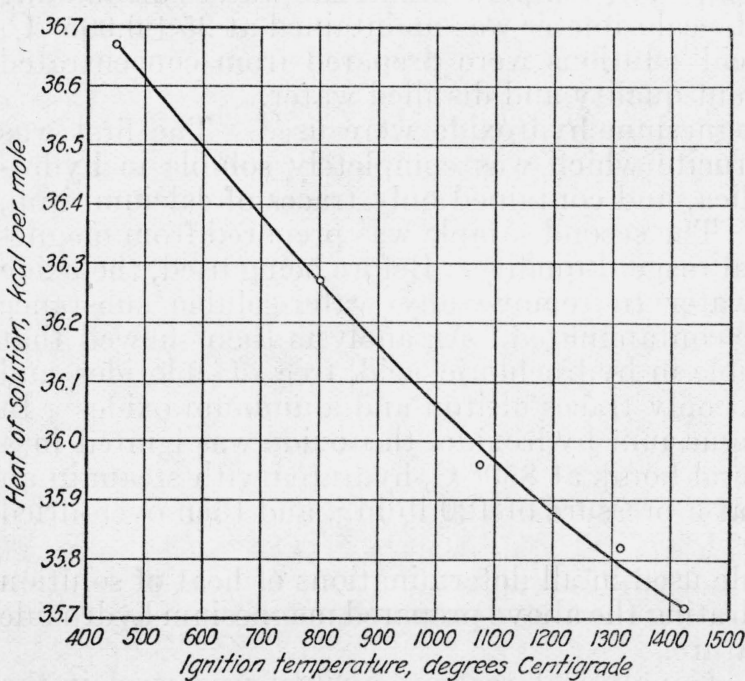

FIGURE 1.-Curve showing the decrease in heat of solution of $\mathrm{MgO}$ prepared by heating $\mathrm{Mg}(\mathrm{OH})_{2}$ for 2.5 hours at increasing temperatures. pared by igniting $\mathrm{Mg}(\mathrm{OH})_{2}$ at $300^{\circ} \mathrm{C}$, as determined by Giauque and Archibald [4].

In order to study the effect of ignition temperature on the heat of solution of $\mathrm{MgO}$, determinations of heat of solution were made on samples of $\mathrm{MgO}$ prepared by heating $\mathrm{Mg}(\mathrm{OH})_{2}$ for 2.5 hours at temperatures ranging from $450^{\circ}$ to $1,425^{\circ} \mathrm{C}$. Data relative to these experiments are given in table 1 . The variation of heat of solution with ignition temperatures may also be seen in figure 1 .

Five heat-capacity measurements made by adding definite amounts of electrical energy to the calorimeter plus $640 \mathrm{~g}$ of $2.085 \mathrm{molal}^{2} \mathrm{HCl}$ solution gave the values $648.1,648.4,648.4,648.0$, and $648.6 \mathrm{cal}$, respectively, or an average of 648.3 cal with the "energy equivalent error" $= \pm 0.2 \mathrm{cal}$.

Table 1 shows that $\mathrm{Mg}(\mathrm{OH})_{2}$ was not completely dehydrated in 2.5 hours at $450^{\circ} \mathrm{C}$ or $800^{\circ} \mathrm{C}$. From the known heat of solution of $\mathrm{Mg}(\mathrm{OH})_{2}$, the heat of solution of $\mathrm{MgO}$ in these samples was corrected for the amount of hydroxide present. Samples used in experiments 1 and 2, determination $A$, represent separate ignitions of $\mathrm{Mg}(\mathrm{OH})_{2}$. In the same way, the sample used in experiment 1 , determination $B$, differs from that used in experiments 2 and 3 of this determination.

From figure 1 it appears probable that at temperatures higher than $1,425^{\circ} \mathrm{C}$ the effect of the temperature of ignition on the heat of

2 The term "molal" (abbreviated $M$ ) in this paper refers to 1 gram-formula weight in 1,000 $\mathrm{g}$ of water 
solution of $\mathrm{MgO}$ would be less than at lower temperatures. In this connection, the heat of solution of periclase (fused $\mathrm{MgO}$ ) would be of interest. However, it has been found that as $\mathrm{MgO}$ is ignited at higher temperatures, it becomes increasingly difficult to dissolve in hydrochloric acid. Samples of periclase, even when ground to pass a standard No. 325 sieve, did not completely dissolve when stirred in the calorimeter for 3 hours (at $25^{\circ} \mathrm{C}$ ) in $4.355 \mathrm{M}$ hydrochloric acid.

TABLE 1.- Heat of solution of samples of $\mathrm{MgO}$ prepared from $\mathrm{Mg}(\mathrm{OH})_{2}$ by ignition for 2.5 hours at various temperatures, using $640 \mathrm{~g}$ of $2.085 \mathrm{M} \mathrm{HCl}$ in each experiment

[Heat capacity of calorimeter containing the initial acid solution equals $648.3 \pm 0.2 \mathrm{cal}$.]

\begin{tabular}{|c|c|c|c|c|c|c|c|c|c|}
\hline \multirow{2}{*}{$\begin{array}{l}\text { Deter- } \\
\text { mina- } \\
\text { tion }\end{array}$} & \multirow{2}{*}{$\begin{array}{l}\text { Temperature } \\
\text { at which MgO } \\
\text { was prepared }\end{array}$} & \multirow{2}{*}{$\begin{array}{l}\text { Ex- } \\
\text { peri- } \\
\text { ment }\end{array}$} & \multirow{2}{*}{$\begin{array}{l}\text { Weight } \\
\text { of } \\
\text { sample } \\
\text { as } \\
\mathrm{MgO}\end{array}$} & \multirow{2}{*}{$\begin{array}{l}\text { Cor- } \\
\text { rected } \\
\text { tem- } \\
\text { pera- } \\
\text { ture } \\
\text { rise }\end{array}$} & \multirow{2}{*}{$\begin{array}{c}\text { Final } \\
\text { tem- } \\
\text { pera- } \\
\text { ture } \\
\text { to } \\
\text { nearest } \\
0.01^{\circ}\end{array}$} & \multirow{2}{*}{$\begin{array}{c}\text { Igni- } \\
\text { tion } \\
\text { loss of } \\
\text { sample }\end{array}$} & \multicolumn{2}{|c|}{$\begin{array}{l}\text { Uncorrected heat } \\
\text { of solution }\end{array}$} & \multirow{2}{*}{$\begin{array}{c}\text { Corrected heat } \\
\text { of solution of } \\
\mathrm{MgO}(\mathrm{c})+17,- \\
630 \mathrm{~g} \mathrm{of} 2.085 \\
M \mathrm{HCl}=\text { solu- } \\
\text { tion; } \\
\Delta H_{298.1{ }^{\circ} \mathrm{K}}\end{array}$} \\
\hline & & & & & & & $\Delta H$ & $\Delta H$ & \\
\hline \multirow[t]{2}{*}{ A... } & \multirow{2}{*}{$\begin{array}{l}\quad{ }^{\circ} \mathrm{C} \\
450 \\
\text { A verage }\end{array}$} & $\left\{\begin{array}{l}1 \\
2\end{array}\right.$ & $\begin{array}{l}g \\
\text { 1. } 3144 \\
1.2547 \\
\end{array}$ & $\begin{array}{l}{ }^{\circ} \mathrm{C} \\
1.8107 \\
1.7282 \\
\end{array}$ & $\begin{array}{l}{ }^{\circ} \mathrm{C} \\
25.85 \\
25.90\end{array}$ & \begin{tabular}{l|}
$\%$ \\
2.80 \\
3.12 \\
\end{tabular} & $\begin{array}{c}\text { cal/g } \\
-909.0 \\
-910.6\end{array}$ & ole & kcal \\
\hline & & $\ldots$ & 1.2845 & 1.7694 & 25.88 & 2.96 & -909.8 & $-36,683$ & $-36.67 \pm 0.07$ \\
\hline \multirow[t]{2}{*}{$B_{-}$} & 800 & $\begin{array}{l}1 \\
2 \\
3\end{array}$ & $\begin{array}{l}1.4986 \\
1.2366 \\
1.6554\end{array}$ & $\begin{array}{l}2.0679 \\
1.7045 \\
2.2822\end{array}$ & $\begin{array}{l}26.01 \\
25.93 \\
26.13\end{array}$ & $\begin{array}{l}0.89 \\
1.00 \\
1.00\end{array}$ & $\begin{array}{l}-899.7 \\
-899.2 \\
-899.6\end{array}$ & & (-n- \\
\hline & \multirow{2}{*}{ A verage } & $\cdots$ & 1.4635 & 2.0182 & 26.02 & 0.96 & -899.5 & $-36,268$ & $-36.27 \pm 0.02$ \\
\hline & & $\begin{array}{l}1 \\
2 \\
3 \\
\end{array}$ & $\begin{array}{l}\text { 1. } 8218 \\
\text { 1. } 4365 \\
\text { 1. } 5968 \\
\end{array}$ & $\begin{array}{l}2.4998 \\
1.9744 \\
2.1930 \\
\end{array}$ & $\begin{array}{l}26.38 \\
26.02 \\
26.10\end{array}$ & & $\begin{array}{l}-891.5 \\
-891.5 \\
-890.8 \\
\end{array}$ & & \\
\hline & Average & $\cdots$ & 1.6193 & 2. 2224 & 26.17 & $\ldots$ & -891.3 & $-35,937$ & $-35.96 \pm 0.02$ \\
\hline \multirow[t]{4}{*}{$D_{\ldots}$} & \multirow{2}{*}{ Average } & & $\begin{array}{l}1.7325 \\
1.8511\end{array}$ & $\begin{array}{l}2.3714 \\
2.5318\end{array}$ & $\begin{array}{l}26.20 \\
26.39\end{array}$ & - & $\begin{array}{l}-888.0 \\
-887.3\end{array}$ & & 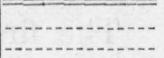 \\
\hline & & $\ldots$ & 1. 7918 & 2.4516 & 26.30 & - & -887.7 & $-35,792$ & $-35.82 \pm 0.03$ \\
\hline & 1,425 & $\begin{array}{l}1 \\
2 \\
\end{array}$ & $\begin{array}{l}\text { 1. } 6351 \\
\text { 1. } 4755 \\
\end{array}$ & $\begin{array}{l}2.2314 \\
2.0148 \\
\end{array}$ & $\begin{array}{l}26.11 \\
26.19\end{array}$ & - & $\begin{array}{l}-885.2 \\
-885.7\end{array}$ & & 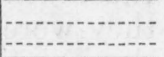 \\
\hline & Averas & & 1. 5553 & 2. 1231 & 26.15 & -- & -885.5 & $-35,703$ & $-35.72 \pm 0.03$ \\
\hline
\end{tabular}

Although a comprehensive study was not made of this phase of the problem, it appears probable that the time of ignition also affects the heat of solution of $\mathrm{MgO}$. It seems, however, that relatively large differences in time are necessary before this effect becomes significant, as is indicated by the data of table 2. The heat of solution of $\mathrm{MgO}$ heated for 18 hours at $800^{\circ} \mathrm{C}$ (table 2 ) is an average of two determinations which differed by $1.3 \mathrm{cal} / \mathrm{g}$; that of the $\mathrm{MgO}$ heated for 4 hours at $1,075^{\circ} \mathrm{C}$ is an average of four determinations which differed by a maximum of $1.5 \mathrm{cal} / \mathrm{g}$.

The differences in the heat of solution of $\mathrm{MgO}$, as shown in tables 1 and 2 , are ascribed mainly to differences in surface. X-ray diffraction patterns were similar, indicating no change in crystalline form. An increase in temperature of ignition resulted in a decrease in the rate of solution in the calorimeter, and, as is well known, it also is followed by a decrease in the rate of hydration. Both effects can be explained by an increase in particle size. Sedimentation experiments in anhydrous normal butyl alcohol showed that the sample of $\mathrm{MgO}$ heated at $800^{\circ} \mathrm{C}$ contained considerable material less than 1 micron 
in diameter, and that much of this in turn was less than 0.5 micron. On the other hand, the $\mathrm{MgO}$ heated at $1,315^{\circ} \mathrm{C}$ had very little material finer than 1 micron.

TABLE 2.-Effect of time of ignition on the heat of solution of $\mathrm{MgO}$ in hydrochloric acid

\begin{tabular}{|c|c|c|}
\hline Temperature of ignition at which $\mathrm{MgO}$ was prepared & $\begin{array}{l}\text { Time of } \\
\text { ignition }\end{array}$ & $\begin{array}{l}\text { Corrected heat of } \\
\text { Isolution of } \mathrm{MgO} \\
\text { (c) }+17,630 \mathrm{~g} \text { of } \\
2.085 \mathrm{MHCl}=\mathrm{So}- \\
\text { lution; } \Delta H 298.1^{\circ} \mathrm{K} \\
\text { equals: }\end{array}$ \\
\hline $\begin{array}{l}800^{\circ} C_{\ldots} \\
1,075^{\circ} C_{\ldots}\end{array}$ & $\begin{array}{r}\text { Hours } \\
2.5 \\
18.0 \\
2.5 \\
4.0\end{array}$ & $\begin{aligned} & k c a l \\
&-36.27 \pm 0.02 \\
&-35.99 \pm 0.05 \\
&-35.96 . \pm 0.02 \\
&-35.94 \pm 0.06\end{aligned}$ \\
\hline
\end{tabular}

\section{CORRECTIONS}

By means of several minor corrections the various average heats of solution were reduced to a comparable basis and expressed as the heats of a definite chemical reaction in which the only variable was the temperature at which the $\mathrm{MgO}$ was ignited. These values are shown in the last column of table 1 .

In making corrections, the following factors were considered: (1) Variation of the concentration of $\mathrm{MgCl}_{2}$ in the final solutions; (2) variation of the concentration of $\mathrm{HCl}$ in the final solutions; and (3) variation of the final temperature from $25^{\circ} \mathrm{C}$.

\section{(a) CORRECTIONS TO COMMON CONCENTRATIONS}

The first two factors are concerned with concentrations in the calorimetric solutions. These concentrations are shown in table 3. Inasmuch as they differed, all determinations were corrected so that they were on a basis equivalent to that of determination $B$ for which the equation in the last column of table 1 was written.

TABLE 3.-Concentration conditions of the calorimetric solutions before and after samples of $\mathrm{MgO}$ have been dissolved

\begin{tabular}{|c|c|c|c|c|c|}
\hline \multirow{2}{*}{ Determination } & \multicolumn{2}{|c|}{$\begin{array}{l}\text { Concentration conditions } \\
\text { in the original solution }\end{array}$} & \multicolumn{3}{|c|}{$\begin{array}{l}\text { Concentration conditions in the final } \\
\text { solution }\end{array}$} \\
\hline & $\underset{\text { of } \mathrm{HCl}}{\text { Amount }}$ & $\begin{array}{l}\text { Concentra- } \\
\text { tion of } \mathrm{HCl}\end{array}$ & $\begin{array}{l}\text { Amount } \\
\text { of } \mathrm{HCl}\end{array}$ & $\begin{array}{l}\text { Concentra- } \\
\text { tion of } \mathrm{HCl}\end{array}$ & $\begin{array}{l}\text { Concentra- } \\
\text { tion of } \mathrm{MgCl}_{2}\end{array}$ \\
\hline $\begin{array}{l}1 \\
4 \\
4\end{array}$ & $\begin{array}{r}\text { Moles per } \\
\text { mole of Mgo } \\
38.9314 \\
34.1698 \\
30.9013 \\
27.9089 \\
32.1530\end{array}$ & $\begin{array}{r}\text { Moles per } \\
1,000 \mathrm{~g} \text { of } \mathrm{H}_{2} \mathrm{O} \\
2.0852 \\
2.0852 \\
2.0852 \\
2.0852 \\
2.0852\end{array}$ & $\begin{array}{c}\text { Moles per } \\
\text { mole of } \mathrm{MgCl}_{2} \\
36.9314 \\
32.1698 \\
28.9013 \\
25.9089 \\
30.1530\end{array}$ & $\begin{array}{r}\text { Moles per } \\
1,000 \mathrm{~g} \text { of } \mathrm{H}_{2} \mathrm{O} \\
1.9761 \\
1.9610 \\
1.9479 \\
1.9331 \\
1.9533\end{array}$ & $\begin{array}{r}\text { Moles per } \\
1,000 \text { o of } \mathrm{H}_{2} \mathrm{O} \\
0.0535 \\
.0610 \\
.0674 \\
.0746 \\
.0648\end{array}$ \\
\hline
\end{tabular}

The last column of table 3 shows the concentration of $\mathrm{MgCl}_{2}$ in the final solutions. The corrections to be applied for the differences shown in this column are, therefore, the heats of dilution or of concentration of a mole of $\mathrm{MgCl}_{2}$ from the various concentrations to a 
concentration of $0.0610 M$. Expressed in other words, they are the differences in the apparent molal heat content of $\mathrm{MgCl}_{2}$ in a 0.0610 $M$ solution and in solutions of the other concentrations. However, the effect of concentration on the apparent molal heat content should be determined in approximately $2 \mathrm{M} \mathrm{HCl}$ rather than in water alone since the former represents the experimental conditions. That the concentration effects differ decidedly under the two conditions may be seen from figure 2, which shows the effect of concentration on the

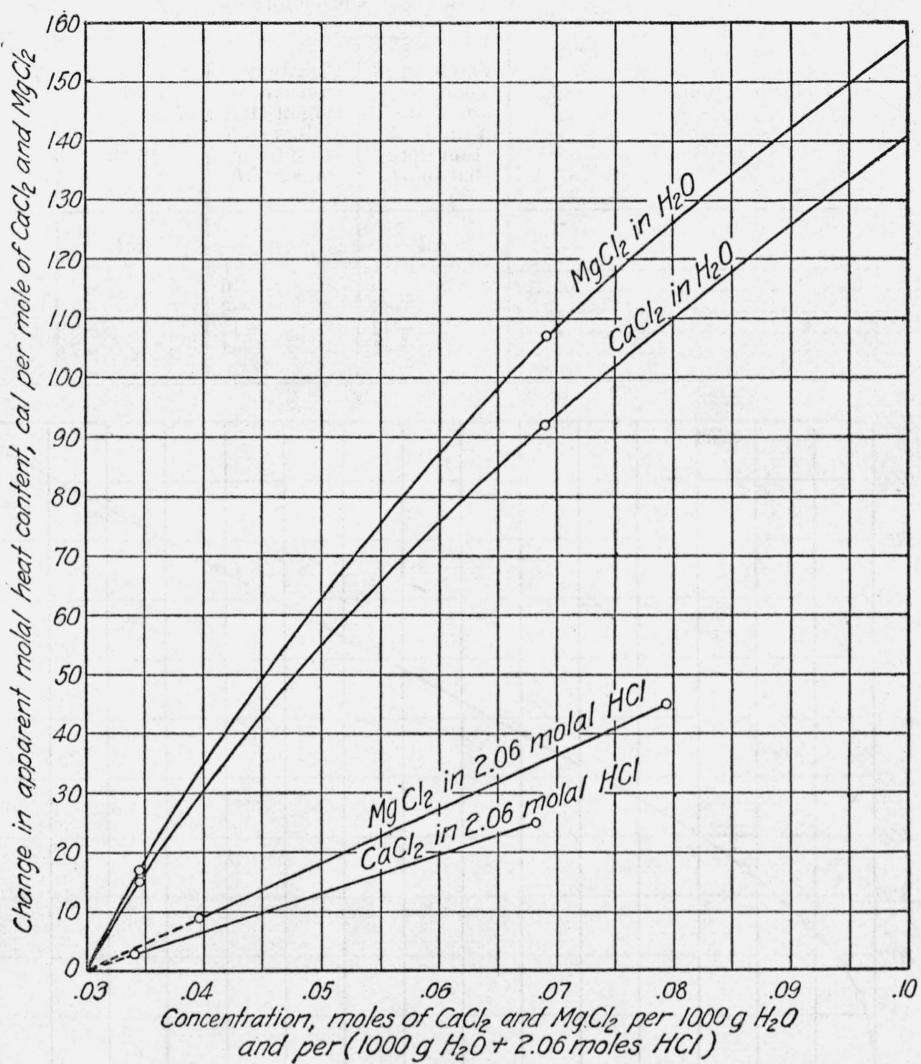

FIGURE 2.-Curves showing the changes in apparent molal heat content of $\mathrm{CaCl}_{2}$ and $\mathrm{MgCl}_{2}$ as functions of their concentrations in water and a hydrochloricacid solution.

The curves for $\mathrm{MgCl}_{3}$ and $\mathrm{CaCl}_{2}$ in water were drawn from data given by Bichowsky and Rossini, Thermochemistry of Chemical Substances, p. 113 and 117, Reinhold Publishing Corporation, New York, N. Y. 1936 , and corrected from $18^{\circ}$ to $25^{\circ} \mathrm{C}$.

change of the apparent molal heat content of $\mathrm{MgCl}_{2}$ and $\mathrm{CaCl}_{2}$ in water and in $2.06 \mathrm{M} \mathrm{HCl}$ at $25^{\circ} \mathrm{C}$. The curves for $\mathrm{MgCl}_{2}$ and $\mathrm{CaCl}_{2}$ in water were drawn from reliable data found in the literature [5] and corrected from $18^{\circ}$ to $25^{\circ} \mathrm{C}$. The graphs for $\mathrm{MgCl}_{2}$ and $\mathrm{CaCl}_{2}$ in hydrochloric acid represent values obtained in this laboratory. As the two latter graphs each represent only two experimental points, they were drawn as straight lines although it is probable that they deviate from such. 
By means of the curve in figure 2 showing the effect of concentration on the apparent molal heat content of $\mathrm{MgCl}_{2}$ in $2.06 \mathrm{M} \mathrm{HCl}$, the concentrations of $\mathrm{MgCl}_{2}$ in the final calorimetric solutions were corrected to a molality of 0.0610 . These corrections are shown in the second column of table 4 .

TABLE 4.-Corrections of $\Delta H$ for the solution of 1 mole of $\mathrm{MgO}$ in 2.0852 $M$ hydrochloric acid

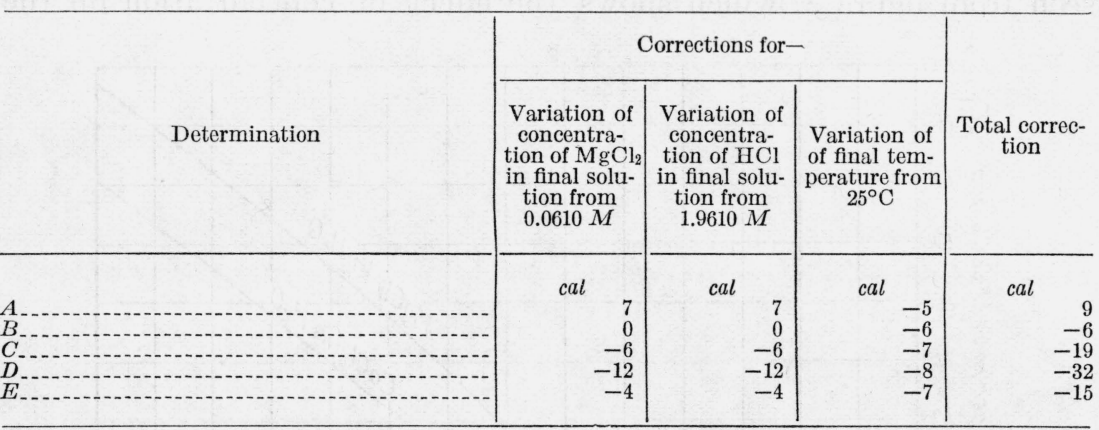

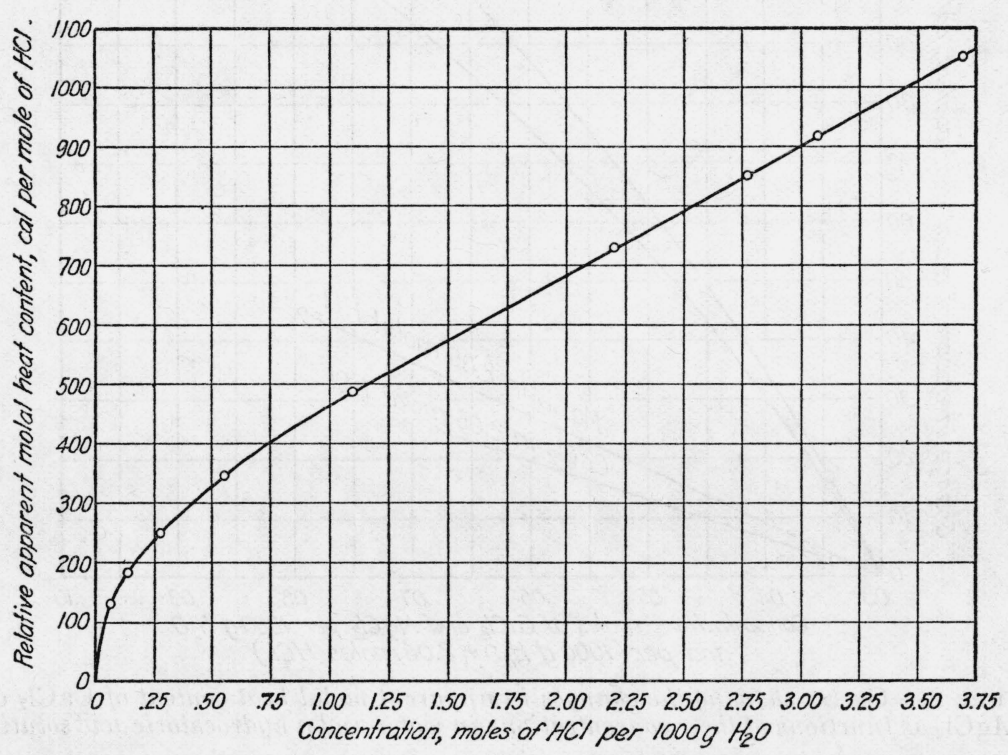

Figure 3.-Relation between tive relative apparent molal heat content of $\mathrm{HCl}$ and concentration.

Drawn from data of Rossini, BS J. Research S 9, 678 (1932) RP499.

When 1 mole of $\mathrm{MgO}$ dissolves in a solution of hydrochloric acid, 2 moles of $\mathrm{HCl}$ disappear from the solution and 1 mole of $\mathrm{H}_{2} \mathrm{O}$ is added. This results in the dilution of the solution which now contains $(n-2)$ moles of $\mathrm{HCl}$, where $n$ is the number of moles of $\mathrm{HCl}$ in the original acid solution per mole of $\mathrm{MgO}$ added. Since the weight of the samples of $\mathrm{MgO}$ differed the number of moles of $\mathrm{HCl}$ in the solutions which were diluted in the determinations differed as did also the extent of dilution. From calculations of $\Delta H$ for the dilution which took place 
in the hydrochloric acid solutions (disregarding for the time being the effect of $\mathrm{MgCl}_{2}$ in these solutions) the final corrections necessary to make all determinations comparable, so far as concentrations are concerned, can be applied.

In order to calculate these heats of dilution it is necessary to know: (1) The number of moles of $\mathrm{HCl}$ involved in each determination; (2) the extent of dilution; and (3) the variation of the apparent molal heat content of $\mathrm{HCl}$ in aqueous solutions with concentration at the temperature and in the concentration range under consideration. The last factor is shown in figure 3, which has been drawn from data of Rossini [6]. From figure 3 it may be seen that at concentrations of about $2 M$ and at a temperature of $25^{\circ} \mathrm{C}$, the apparent molal heat content of $\mathrm{HCl}$ changes approximately 220 cal for a change of 1 in molality. Column 4 of table 3 shows the number of moles of $\mathrm{HCl}$ diluted in the various determinations. The extent of dilution is obtained by subtracting each of the numbers in column 5 of table 3 from 2.0852 , the concentration of $\mathrm{HCl}$ in the original acid solution. The product of these three factors is the heat produced by the dilution of the acid solution (neglecting the $\mathrm{MgCl}_{2}$ ) when 1 mole of $\mathrm{MgO}$ is dissolved. These heats of dilution are shown in table 5 .

It should be pointed out that although these solutions contain $\mathrm{MgCl}_{2}$ in various amounts, corrections have already been made for the differences in the apparent molal heat content of the $\mathrm{MgCl}_{2}$ (see table 4). The presence of $\mathrm{MgCl}_{2}$ should, therefore, be disregarded in this method of correcting for differences in the concentration of $\mathrm{HCl}$ in the final solutions as will be apparent on consideration of the equations which follow.

TABLE 5.-Heat absorbed by the dilution of the hydrochloric acid solution disregarding the $\mathrm{MgCl}_{2}$ formed when 1 mole of $\mathrm{MgO}$ is dissolved

\begin{tabular}{|c|c|c|}
\hline $\begin{array}{l}\text { Determina- } \\
\text { tion }\end{array}$ & Reaction & $\Delta H_{288.10^{\circ} \mathrm{K}}$ \\
\hline 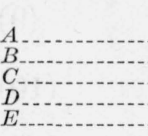 & $\begin{array}{l}36.9314 \mathrm{HCl}(\mathrm{aq}, M=2.0852)=36.9314 \mathrm{HCl}(\mathrm{aq}, M=1.9761) \\
32.1698 \mathrm{HCl}(\mathrm{aq}, M=2.0852)=32.1698 \mathrm{HCl}(\mathrm{aq}, M=1.9610) \\
28.9013 \mathrm{HCl}(\mathrm{aq}, M=2.0852)=28.9013 \mathrm{HCl}(\mathrm{aq}, M=1.9179) \\
25.9009 \mathrm{HCl}(\mathrm{aq}, M=2.0852)=25.9089 \mathrm{HCl}, M=1.931) \\
30.1530 \mathrm{HCl}(\mathrm{aq}, M=2.0852)=30.1530 \mathrm{HCl}(\mathrm{aq}, M=1.9533) \\
\end{array}$ & cal $\begin{aligned}-886 \\
-879 \\
-873 \\
-867 \\
-875\end{aligned}$ \\
\hline
\end{tabular}

Equations 1 and 2 pertain to determinations $B$ and $D$, respectively.

$$
\begin{gathered}
\mathrm{MgO}(\mathrm{c})+34.1698 \mathrm{HCl}(\mathrm{aq}, M=2.0852)=\left[\mathrm{MgCl}_{2}(M=0.0610)\right. \\
+32.1698 \mathrm{HCl}(M=1.9610)](\mathrm{aq}) ; \Delta H_{1} . \\
\mathrm{MgO}(\mathrm{c})+27.9089 \mathrm{HCl}(\mathrm{aq}, M=2.0852)=\left[\mathrm{MgCl}_{2}(M=0.0746)\right. \\
+25.9089 \mathrm{HCl}(M=1.9331)](\mathrm{aq}) ; \Delta H_{2} .
\end{gathered}
$$

It will be assumed for the time being that the samples of $\mathrm{MgO}$ have been prepared in the same way and that the environments of the two determinations are comparable in all respects except for concentration. The difference in the heats of the two reactions, $\Delta H_{1}-\Delta H_{2}$, therefore, represents the amount that must be added to $\Delta H_{2}$ to correct the conditions of determination $D$ to those of determination $B$. 
Subtracting eq 2 from eq 1 and transposing terms there is obtained

$$
\begin{gathered}
34.1698 \mathrm{HCl}(\mathrm{aq}, M=2.0852)+\left[\mathrm{MgCl}_{2}(M=0.0746)\right. \\
+25.9089 \mathrm{HCl}(M=1.9331)](\mathrm{aq}) \\
=\left[\mathrm{MgCl}_{2}(M=0.0610)+32.1698 \mathrm{HCl}(M=1.9610)\right](\mathrm{aq}) \\
+27.9089 \mathrm{HCl}(\mathrm{aq}, M=2.0852) ; \Delta H_{3}=\Delta H_{1}-\Delta H_{2} .
\end{gathered}
$$

From an inspection of figure 2 it may be seen that the apparent molal heat contents of 0.0746 and $0.0610 \mathrm{M} \mathrm{MgCl}$ in approximately $2 \mathrm{M}$ $\mathrm{HCl}$ differ by about $12 \mathrm{cal}$ (40-28, approximately). Making the appropriate correction in the heat of the reaction as indicated by this approximate value, the two moles of $\mathrm{MgCl}_{2}$ may be omitted from eq 3 and the reaction written as

$$
\begin{gathered}
34.1698 \mathrm{HCl}(\mathrm{aq}, M=2.0852)+25.9089 \mathrm{HCl}(\mathrm{aq}, M=1.9331) \\
=32.1698 \mathrm{HCl}(\mathrm{aq}, M=1.9610)+27.9089 \mathrm{HCl}(\mathrm{aq}, M=2.0852) ; \\
\Delta H_{4}=\Delta H_{3}+12 \mathrm{cal}=\Delta H_{1}-\Delta H_{2}+12 \mathrm{cal} .
\end{gathered}
$$

Subtracting

$$
2 \mathrm{HCl}(\mathrm{aq}, M=2.0852)=2 \mathrm{HCl}(\mathrm{aq}, M=2.0852) ; \Delta H_{5}=0
$$

from eq 4 , there is obtained

$32.1698 \mathrm{HCl}(\mathrm{aq}, M=2.0852)+25.9089 \mathrm{HCl}(\mathrm{aq}, M=1.9331)=$

$32.1698 \mathrm{HCl}(\mathrm{aq}, M=1.9610)+25.9089 \mathrm{HCl}(\mathrm{aq}, M=2.0852)$;

$$
\Delta H_{6}=\Delta H_{4}-\Delta H_{5}=\Delta H_{1}-\Delta H_{2}+12 \text { cal. }
$$

Equation 6 is also obtained when eq 8 is subtracted from eq 7 $32.1698 \mathrm{HCl}(\mathrm{aq}, M=2.0852)=32.1698 \mathrm{HCl}(\mathrm{aq}, M=1.9610) ; \Delta H_{7}$

$25.9089 \mathrm{HCl}(\mathrm{aq}, M=2.0852)=25.9089 \mathrm{HCl}(\mathrm{aq}, M=1.9331) ; \Delta H_{8}$

Therefore,

and

$$
\Delta H_{6}=\Delta H_{7}-\Delta H_{8}=\Delta H_{1}-\Delta H_{2}+12 \mathrm{cal}
$$

$$
\Delta H_{1}-\Delta H_{2}=\Delta H_{7}-\Delta H_{8}-12 \mathrm{cal} \text {. }
$$

From table 5 it may be seen that eq 7 and 8 represent the reactions for the dilution of the acid solutions in determinations $B$ and $D$, respectively. Since account has already been taken of the -12 cal in eq 10 in correcting for the variation of the concentration of $\mathrm{MgCl}_{2}$ in the final solutions (see table 3 ) the only remaining correction to be made for differences in concentration is $\Delta H_{7}-\Delta H_{8}$, which, as can be seen from table 5 , is equal to $-879-(-867)$ or -12 cal.

Since the concentrations of all determinations were corrected to those of determination $B$, the corrections for differences in the concentration of $\mathrm{HCl}$ in the final solutions were obtained by subtracting each of the numbers in the last column of table 5 from $-879 \mathrm{cal}$.

These corrections are shown in the third column of table 4 .

(b) CORRECTION TO A TEMPERATURE OF $25^{\circ} \mathrm{C}$

As it was desired to know the heats of the reactions at $25^{\circ} \mathrm{C}$, corrections were made for the departure of the final temperatures from $25^{\circ} \mathrm{C}$. 
In calculating the temperature coefficient of the reaction, $\mathrm{MgO}(\mathrm{c})+$ $2 \mathrm{HCl}(\mathrm{aq})=\mathrm{MgCl}_{2}(\mathrm{aq})+\mathrm{H}_{2} \mathrm{O}$ (liq), in which the concentrations of the $\mathrm{HCl}$ and $\mathrm{MgCl}_{2}$ solutions were approximately 2 and $0.06 \mathrm{M}$, respectively, the apparent molal heat capacity (at $25^{\circ} \mathrm{C}$ ) of $2 \mathrm{HCl}$ was taken as $-45 \mathrm{cal} /{ }^{\circ} \mathrm{C}$ [7] and that of $\mathrm{MgCl}_{2}$ as $-48 \mathrm{cal} /{ }^{\circ} \mathrm{C}$. The latter was estimated from specific-heat data on aqueous solutions of $\mathrm{MgCl}_{2}$ [8]. The molal heat capacities of $\mathrm{MgO}$ [4] and $\mathrm{H}_{2} \mathrm{O}$ were taken as $9.1 \mathrm{cal} /{ }^{\circ} \mathrm{C}$ and $18 \mathrm{cal} /{ }^{\circ} \mathrm{C}$, respectively, at $25^{\circ} \mathrm{C}$. The increase in the heat capacity, $\Delta C_{p}$, resulting from the above reaction is, therefore, $(-48+18)-(9.1+(-45))$, or approximately +6 cal.

Since

and

$$
\Delta H_{2}-\Delta H_{1}=\Delta C_{p}\left(T_{2}-T_{1}\right)
$$

$$
\Delta H_{1}=-\Delta C_{p}\left(T_{2}-T_{1}\right)+\Delta H_{2},
$$

the temperature coefficient of the reaction in question is $-6 \mathrm{cal} /{ }^{\circ} \mathrm{C}$. To obtain the temperature corrections it is only necessary then to subtract $25^{\circ} \mathrm{C}$ from the final temperature of each determination and multiply each result by -6 cal. These corrections are shown in the fourth column of table 4 .

\section{HEAT OF SOLUTION OF $\mathrm{Mg}(\mathrm{OH})_{2}$ IN HYDROCHLORIC ACID}

Determinations were made of the heat of solution (in $2.085 \mathrm{M} \mathrm{HCl}$ ) of brucite and of $\mathrm{Mg}(\mathrm{OH})_{2}$ prepared by hydrating $\mathrm{MgO}$ for 2 hours at $120 \mathrm{lb} /$ in. $^{2}$ steam pressure (see section III). Data relative to these determinations are shown in table 6 . The method by which the corrected heats of solution were obtained was explained in detail in section IV of this paper.

TABLE 6.-Heat of solution of $\mathrm{Mg}(\mathrm{OH})_{2}$ in $2.085 \mathrm{M} \mathrm{HCl}$

\begin{tabular}{|c|c|c|c|c|}
\hline \multirow{2}{*}{ Sample } & \multirow{2}{*}{$\begin{array}{l}\text { Experi- } \\
\text { ment }\end{array}$} & \multicolumn{2}{|c|}{$\begin{array}{l}\text { Uncorrected heat of } \\
\text { solution }\end{array}$} & \multirow{2}{*}{$\begin{array}{l}\text { Corrected heat of so- } \\
\text { lution of } \mathrm{Mg}(\mathrm{OH})_{2} \\
\text { (c) }+17,630 \mathrm{~g} 2.085 \\
M \mathrm{HCl}-\mathrm{H}_{2} \mathrm{O} \text { (liq) } \\
\text { =solution } \Delta \mathrm{H}_{248 \cdot 1^{\circ} \mathrm{K}} \\
\text { equals: }\end{array}$} \\
\hline & & $\Delta H$ & $\Delta H$ & \\
\hline $\mathrm{Mg}(\mathrm{OH})_{2}$ (brucite) & $\begin{array}{l}1 \\
2 \\
3\end{array}$ & $\begin{array}{r}\text { cal/g of } \mathrm{MgO} \\
-661.2 \\
-661.6 \\
-661.4\end{array}$ & $\begin{array}{c}\text { cal/mole } \\
-1 \\
\end{array}$ & $\begin{array}{c}\text { kcal } \\
\end{array}$ \\
\hline Average... & - & -661.4 & $-26,672$ & $-26.64 \pm 0.01$ \\
\hline $\begin{array}{l}\mathrm{Mg}(\mathrm{OH})_{2} \text { prepared by hydrating } \mathrm{MgO} \text { for } 2 \mathrm{hr} \\
\text { at } 120-1 \mathrm{~b} / \text { in. }^{2} \text { steam pressure, } 177^{\circ} \mathrm{C}\end{array}$ & $\begin{array}{l}1 \\
2 \\
3 \\
4\end{array}$ & $\begin{array}{l}-666.9 \\
-667.9 \\
-668.2 \\
-667.0\end{array}$ & 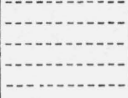 & 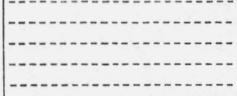 \\
\hline Average... & 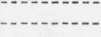 & -667.5 & $-26,917$ & $-26.88 \pm 0.0$ \\
\hline
\end{tabular}

[Heat capacity of calorimeter containing $640 \mathrm{~g}$ of $2.085 \mathrm{M} \mathrm{HCl}$ equals $648.3 \pm 0.2$ cal.]

Table 6 shows that the heat of solution of brucite is appreciably less than that of the $\mathrm{Mg}(\mathrm{OH})_{2}$ prepared by the hydration of $\mathrm{MgO}$ in the autoclave. 


\section{HEATS OF SOLUTION OF CaO AND Ca(OH $)_{2}$ IN HYDRO- CHLORIC ACID}

The samples of $\mathrm{CaO}$ and $\mathrm{Ca}(\mathrm{OH})_{2}$ used in determinations of heat of solution were described in section III. As is indicated in tables 7 and 8, determinations were made in both 2.085 and $0.277 \mathrm{M} \mathrm{HCl}$. The molal concentrations of $\mathrm{CaCl}_{2}$ in the final solutions represented by the equations in columns 5 of these tables was in both cases $0.0380 \mathrm{M}$.

The effect of ignition temperature on the heat of solution of $\mathrm{CaO}$ has not been studied in this laboratory. However, Gautier [9] has reported heat of solution data on $\mathrm{CaO}$ (in hydrochloric acid) prepared by igniting $\mathrm{CaCO}_{3}$ at temperatures ranging from $1,000^{\circ}$ to about $2,570^{\circ} \mathrm{C}$ (fusion temperature of $\mathrm{CaO}$ ). He concluded that the temperature at which the $\mathrm{CaO}$ was prepared did not affect its heat of solution. In view of the effect of the ignition temperature on the heat of solution of $\mathrm{MgO}$, it should be of particular interest to compare the heat of solution of $\mathrm{CaO}$ prepared at high temperatures with that prepared by dehydration of $\mathrm{Ca}(\mathrm{OH})_{2}$ at relatively low temperatures.

TABLE 7.-Heat of solution of $\mathrm{CaO}$ and $\mathrm{Ca}(\mathrm{OH})_{2}$ in $2.085 \mathrm{M} \mathrm{HCl}$

[Heat capacity of calorimeter containing $640 \mathrm{~g}$ of $2.085 \mathrm{M}$ HCl equals $648.3 \pm 0.2 \mathrm{cal}$.]

\begin{tabular}{|c|c|c|c|c|}
\hline \multirow{2}{*}{ Sample } & \multirow{2}{*}{$\begin{array}{l}\text { Experi- } \\
\text { ment }\end{array}$} & \multicolumn{2}{|c|}{$\begin{array}{l}\text { Uncorrected heat of } \\
\text { solution }\end{array}$} & \multirow{2}{*}{ Corrected heat of solution } \\
\hline & & $\Delta H$ & $\Delta H$ & \\
\hline $\begin{array}{l}\mathrm{CaO} \text { prepared from } \mathrm{CaCO}_{3} \text { by ig- } \\
\text { niting for } 4 \mathrm{hr} \text {. at } 1,050^{\circ} \text { to } 1,100^{\circ} \\
\mathrm{C} \text {. }\end{array}$ & $\begin{array}{l}1 \\
2 \\
3\end{array}$ & $\begin{array}{r}\text { cal/g of } \mathrm{CaO} \\
-833.6 \\
-835.2 \\
-833.8\end{array}$ & cal/mole & $\left\{\begin{array}{l}\mathrm{CaO}(\mathrm{c})+28,000 \mathrm{~g} \text { of } 2.085 \mathrm{M} \mathrm{HCl}= \\
\text { solution; } \Delta H_{298.1^{\circ} \mathrm{K} \text { equals: }}\end{array}\right.$ \\
\hline Average & $\bar{\ldots}$ & -834.2 & $-46,774$ & $-46.78 \pm 0.06 \mathrm{kcal}$ \\
\hline $\begin{array}{l}\mathrm{Ca}(\mathrm{OH})_{2} \text { prepared by hydrating } \\
\mathrm{CaO} \text { for } 2 \text { hr. at } 120 \text {-lb./in. } .^{2} \text { steam } \\
\text { pressure }\left(177^{\circ} \mathrm{C} \text {. }\right) \text {. }\end{array}$ & $\begin{array}{l}1 \\
2 \\
3\end{array}$ & $\begin{array}{l}-556.8 \\
-557.9 \\
-557.6\end{array}$ & $\ldots$ & $\begin{array}{l}\mathrm{Ca}(\mathrm{OH})_{2}+28,000 \mathrm{~g} \text { of } 2.085 \mathrm{M} \mathrm{HCl}- \\
\mathrm{H}_{2} \mathrm{O}(\mathrm{liq})=\text { solution; } \Delta H_{288.1}{ }^{\circ} \mathrm{K} \\
\text { equals: }\end{array}$ \\
\hline Average & - & -557.4 & $-31,253$ & $-31.23 \pm 0.04 \mathrm{kcal}$ \\
\hline
\end{tabular}

TABLE 8.- Heat of solution of $\mathrm{CaO}$ and $\mathrm{Ca}(\mathrm{OH})_{2}$ in $0.277 \mathrm{M} \mathrm{HCl}$

[Heat capacity of calorimeter containing $640 \mathrm{~g}$ of $0.277 \mathrm{M}$ HCl equals $689.7 \pm 0.9 \mathrm{cal}$. .]

\begin{tabular}{|c|c|c|c|c|}
\hline \multirow{2}{*}{ Sample } & \multirow{2}{*}{$\begin{array}{l}\text { Experi- } \\
\text { ment }\end{array}$} & \multicolumn{2}{|c|}{$\begin{array}{l}\text { Uncorrected heat of } \\
\text { solution }\end{array}$} & \multirow{2}{*}{ Corrected heat of solution } \\
\hline & & $\Delta H$ & $\Delta H$ & \\
\hline $\begin{array}{l}\text { CaO prepared from } \mathrm{CaCO}_{3} \text { by ig- } \\
\text { niting for } 4 \mathrm{hr} \text {. at } 1,050^{\circ} \text { to } 1,100^{\circ} \\
\text { C. }\end{array}$ & $\begin{array}{l}1 \\
2 \\
3\end{array}$ & $\begin{array}{c}\text { cal/g of } \mathrm{CaO} \\
-825.5 \\
-824.2 \\
-825.9\end{array}$ & cal/mole & $\left\{\begin{array}{l}\mathrm{CaO}(\mathrm{c})+27,416 \mathrm{~g} \text { of } 0.277 \mathrm{M} \mathrm{HCl}= \\
\text { solution; } \Delta H_{298.1^{\circ} \mathrm{K} \text { equals: }}\end{array}\right.$ \\
\hline Average & $-1-2--$ & -825.2 & $-46,269$ & $-46.28 \pm 0.07 \mathrm{kcal}$ \\
\hline $\begin{array}{l}\mathrm{Ca}(\mathrm{OH})_{2} \text { prepared by hydrating } \\
\mathrm{CaO} \text { for } 2 \mathrm{hr} \text {. at } 120 \text {-lb./in. }{ }^{2} \text { steam } \\
\text { pressure }\left(177^{\circ} \mathrm{C} .\right) \text {. }\end{array}$ & $\begin{array}{l}1 \\
2 \\
3\end{array}$ & $\begin{array}{l}-547.8 \\
-547.2 \\
-548.5\end{array}$ & 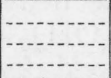 & $\left\{\begin{array}{l}\mathrm{Ca}(\mathrm{OH})_{2}(\mathrm{c})+27,416 \text { g of } 0.277 \underset{M}{\mathrm{M}} \\
\mathrm{HCl}-\mathrm{H}_{2} \mathrm{O}(\mathrm{liq})=\text { solution; } \Delta \mathrm{H}_{298 \cdot 1}{ }^{\circ} \mathrm{K} \\
\text { equals: }\end{array}\right.$ \\
\hline Average & $-\ldots-1$ & -547.8 & $-30,715$ & $-30.70 \pm 0.05 \mathrm{kcal}$ \\
\hline
\end{tabular}




\section{HEATS OF HYDRATION OF MgO AND $\mathrm{CaO}$}

The values which have been reported for the heat of hydration of $\mathrm{MgO}$ to $\mathrm{Mg}(\mathrm{OH})_{2}$ differ considerably, as is indicated by table 9 . Mixter [10] measured the heat of dehydration of brucite. Roth and Chall [11] state that in their experiments Kahlbaum MgO was used, and that the $\mathrm{Mg}(\mathrm{OH})_{2}$ was prepared by the slow reaction of water on this $\mathrm{MgO}$, the resulting product being dried to constant weight at $100^{\circ} \mathrm{C}$. Giauque and Archibald [4] prepared $\mathrm{Mg}(\mathrm{OH})_{2}$ by the precipitation method of de Schulten [12]. They state that the crystals of $\mathrm{Mg}(\mathrm{OH})_{2}$ were well formed, having an average diameter of about $0.2 \mathrm{~mm}$. The $\mathrm{MgO}$ was prepared by the dehydration of the precipitated $\mathrm{Mg}(\mathrm{OH})_{2}$ in vacuo at $300^{\circ} \mathrm{C}$.

TABLE 9.- - Heat of hydration of $\mathrm{MgO}$ to $\mathrm{Mg}(\mathrm{OH})_{2}$ as reported by various investigators

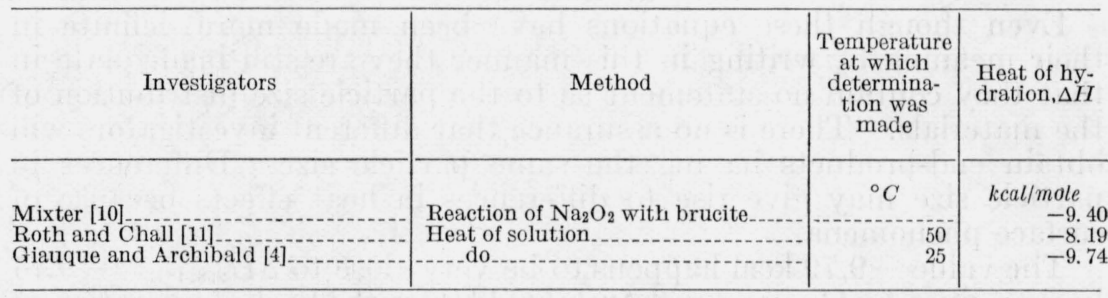

It can be seen from the data of table 1 that the heat of solution of $\mathrm{MgO}$ prepared by dehydrating $\mathrm{Mg}(\mathrm{OH})_{2}$ at $450^{\circ} \mathrm{C}$. was 950 cal per mole greater than that prepared at $1,425^{\circ} \mathrm{C}$. Also (table 6 ) the heat of solution of $\mathrm{Mg}(\mathrm{OH})_{2}$ prepared by hydrating $\mathrm{MgO}$ in the autoclave was $240 \mathrm{cal}$ per mole greater than that of brucite. It should be recalled that Fricke, Schnabel, and Beck [3] have likewise reported differences in the heats of solution of $\mathrm{Mg}(\mathrm{OH})_{2}$ prepared by various methods. It is apparent then that the heat of hydration of $\mathrm{MgO}$ to $\mathrm{Mg}(\mathrm{OH})_{2}$ may vary considerably, depending on characteristic properties of both the $\mathrm{MgO}$ and the $\mathrm{Mg} \cdot(\mathrm{OH})_{2}$ which is formed as the result of the hydration. A heat value for the reaction,

$$
\mathrm{MgO}(\mathrm{c})+\mathrm{H}_{2} \mathrm{O}(\mathrm{liq})=\mathrm{Mg}(\mathrm{OH})_{2}(\mathrm{c}),
$$

as determined from heat of solution data, is therefore indefinite in meaning unless the samples of $\mathrm{MgO}$ and $\mathrm{Mg}(\mathrm{OH})_{2}$, on which many data have been obtained, are fully described.

Table 1 shows the equation $\mathrm{MgO}(\mathrm{c})+17,630 \mathrm{~g}$ of $2.085 \mathrm{M} \mathrm{HCl}=$ solution; $\Delta H_{298.1{ }^{\circ} \mathrm{K}}=-36.67 \mathrm{kcal}$, for the solution of $\mathrm{MgO}$ prepared by dehydrating $\mathrm{Mg}(\mathrm{OH})_{2}$ (c) for 2.5 hours at $450^{\circ} \mathrm{C}$.; table 6 , the equation $\mathrm{Mg}(\mathrm{OH})_{2}(\mathrm{c})+17,630 \mathrm{~g}$ of $2.085 \mathrm{M} \mathrm{HCl}-\mathrm{H}_{2} \mathrm{O}$ (liq) $=$ solution; $\Delta H_{298.1^{\circ} \mathrm{K}}=-26.64 \mathrm{kcal}$ for the solution of brucite. These equations could be made more definite in their meaning by writing them in the following forms:

$\mathrm{MgO}(\mathrm{c})\left[\left(\mathrm{Mg}(\mathrm{OH})_{2}\right.\right.$ dehydrated $2.5 \mathrm{hr}$ at $\left.450^{\circ} \mathrm{C}\right]+17,630 \mathrm{~g}$ of $2.085 \mathrm{M} \mathrm{HCl}=$ solution; $\Delta H_{298.1^{\circ} \mathrm{K}}=-36.67 \mathrm{kcal}$

and 
$\mathrm{Mg}(\mathrm{OH})_{2}(\mathrm{c})$ [brucite] $+17,630 \mathrm{~g}$ of $2.085 \mathrm{M} \mathrm{HCl}-\mathrm{H}_{2} \mathrm{O}$ (liq) $=$ solution; $\Delta H_{298.1^{\circ} \mathrm{K}}=-26.64 \mathrm{kcal}$.

By subtracting eq 12 from eq 11, there is obtained

$\mathrm{MgO}(\mathrm{c})\left[\mathrm{Mg}(\mathrm{OH})_{2}\right.$ dehydrated $2.5 \mathrm{hr}$ at $\left.450^{\circ} \mathrm{C}\right]+\mathrm{H}_{2} \mathrm{O}(\mathrm{liq})=\mathrm{Mg}(\mathrm{OH})_{2}$ [brucite]; $\Delta H_{298.1^{\circ} \mathrm{K}}=-10.03 \pm 0.07$ kcal.

From similar considerations, there may also be written

$\mathrm{MgO}\left(\right.$ c) $\left[\mathrm{Mg}(\mathrm{OH})_{2}\right.$ dehydrated $2.5 \mathrm{hr}$ at $\left.1,425^{\circ} \mathrm{C}\right]+\mathrm{H}_{2} \mathrm{O}(\mathrm{liq})=\mathrm{Mg}$ $(\mathrm{OH})_{2}(\mathrm{c})\left[\mathrm{MgO}\right.$ hydrated $2 \mathrm{hr}$ with saturated steam at $\left.177^{\circ} \mathrm{C}\right]$; $\Delta \mathrm{H}_{298.1^{\circ} \mathrm{K}}=-8.84 \pm 0.05 \mathrm{kcal}$.

Still other values for the heat of hydration of $\mathrm{MgO}$ can be calculated from the present data, for example: $\mathrm{MgO}(\mathrm{c})\left[\mathrm{Mg}(\mathrm{OH})_{2}\right.$ dehydrated $2.5 \mathrm{hr}$ at $\left.450^{\circ} \mathrm{C}\right]+\mathrm{H}_{2} \mathrm{O}$ (liq) $=\mathrm{Mg}(\mathrm{OH})_{2}$ (c) $[\mathrm{MgO}$ hydrated $2.5 \mathrm{hr}$ with saturated steam at $\left.177^{\circ} \mathrm{C}\right] ; \Delta H_{298 \cdot 1{ }^{\circ} \mathrm{K}}=-9.79 \pm 0.07 \mathrm{kcal}$.

Even though these equations have been made more definite in their meaning by writing in this manner they are still inadequate in that they contain no statement as to the particle size distribution of the materials. There is no assurance that different investigators will obtain end-products having the same particle size. Differences in particle size may give rise to differences in heat effects because of surface phenomena.

The value $-9.79 \mathrm{kcal}$ happens to be very close to $\Delta H_{298.1^{\circ} \mathrm{K}}=-9.74$ $\mathrm{kcal}$ as given by Giauque and Archibald [4] for the heat of hydration of $\mathrm{MgO}$ to $\mathrm{Mg}(\mathrm{OH})_{2}$ computed from their excellent heat-of-solution data. However, inasmuch as their sample of $\mathrm{Mg}(\mathrm{OH})_{2}$ was composed of crystals having an average diameter of about $0.2 \mathrm{~mm}$, their value should perhaps be compared to $-10.03 \mathrm{kcal}$ obtained from eq 13 , which pertains to well-developed crystals of brucite, were it not for the fact their $\mathrm{MgO}$ was prepared somewhat differently from that given in eq 13. They decomposed their $\mathrm{Mg}(\mathrm{OH})_{2}$ under vacuum at $300^{\circ} \mathrm{C}$, raising the temperature to $350^{\circ} \mathrm{C}$ toward the end of the decomposition. Apparently, this required 10 days or more of heating. The $\mathrm{MgO}$ used in the present investigation was prepared not from brucite but from $\mathrm{Mg}(\mathrm{OH})_{2}$ obtained with the use of saturated steam. It is believed that differences in the particle size of the samples of $\mathrm{MgO}$ largely account for differences in the heats of hydration of $\mathrm{MgO}$ to $\mathrm{Mg}(\mathrm{OH})_{2}$.

TABLE 10.- Heat of hydration of $\mathrm{CaO}$ to $\mathrm{Ca}(\mathrm{OH})_{2}$ as reported by various investigators

\begin{tabular}{|c|c|c|c|}
\hline Investigators & Method & $\begin{array}{c}\text { Temperature } \\
\text { at which the } \\
\text { determina. } \\
\text { tion was } \\
\text { made }\end{array}$ & $\begin{array}{l}\text { Heat of hy- } \\
\text { dration }\end{array}$ \\
\hline $\begin{array}{l}\text { Thomsen [13] } \\
\text { Berthelot [14] }\end{array}$ & $\begin{array}{l}\text { Heat of solution } \\
\text { Heat of solution and heat of neu- }\end{array}$ & $\begin{array}{ll}{ }^{\circ} \mathrm{C} & \\
& 20 \\
& 16\end{array}$ & $\begin{array}{r}\text { kcal/mole } \\
15.54 \\
15.10\end{array}$ \\
\hline 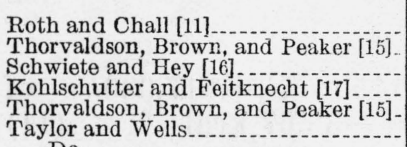 & $\begin{array}{l}\text { tralization. } \\
\text { Heat of solution } \\
\text { Direct hydration. } \\
\text { Heat of solution }\end{array}$ & $\begin{array}{l}50 \\
20 \\
18 \\
20 \\
20 \\
25\end{array}$ & $\begin{array}{r}15.44 \\
15.64 \\
15.55 \\
15.30 \\
15.49 \\
15.57 \pm 0.88\end{array}$ \\
\hline Do.- & Direct hydration... & 25 & $\begin{array}{l}15.43 \pm 0.88 \\
15.48\end{array}$ \\
\hline
\end{tabular}


The heat of hydration of $\mathrm{CaO}$ to $\mathrm{Ca}(\mathrm{OH})_{2}$ has been determined by various investigators by differences in the heats of solution of $\mathrm{CaO}$ and $\mathrm{Ca}(\mathrm{OH})_{2}$ in an acid as well as by direct hydration in saturated lime water. The results of these determinations are shown in table 10.

In this investigation the heat of hydration of $\mathrm{CaO}$ was determined by both the heat-of-solution and direct method. The heats of solution of $\mathrm{CaO}$ and $\mathrm{Ca}(\mathrm{OH})_{2}$ were each determined in two concentrations of hydrochloric acid (see tables 7 and 8). Modifying the equations in table 7 to describe more definitely the states of the solids, there may be written

$\mathrm{CaO}$ (c) $\left[\mathrm{CaCO}_{3}\right.$ ignited $4 \mathrm{hr}$ at $\left.1,075^{\circ} \mathrm{C}\right]+28,300 \mathrm{~g}$ of $2.085 \mathrm{M} \mathrm{HCl}$ $=$ solution]; $\Delta H_{288.1^{\circ} \mathrm{K}}=-46.78 \mathrm{kcal}$.

$\mathrm{Ca}(\mathrm{OH})_{2}$ (c) $\left[\mathrm{CaO}\right.$ hydrated $2 \mathrm{hr}$ with saturated steam at $\left.177^{\circ} \mathrm{C}\right]$ $+28,300 \mathrm{~g}$ of $2.085 \mathrm{M} \mathrm{HCl}-\mathrm{H}_{2} \mathrm{O}$ (liq)=solution;

$$
\Delta H_{298.1^{\circ} \mathrm{K}}=-31.23 \mathrm{kcal} \text {. }
$$

Subtracting eq 17 from eq 16 there is obtained

$\mathrm{CaO}$ (c) $\left[\mathrm{CaCO}_{3}\right.$ ignited $4 \mathrm{hr}$ at $\left.1,075^{\circ} \mathrm{C}\right]+\mathrm{H}_{2} \mathrm{O}$ (liq) $=\mathrm{Ca}(\mathrm{OH})_{2}$ (c) [CaO hydrated $2 \mathrm{hr}$ with saturated steam at $177^{\circ} \mathrm{C}$;

$$
\Delta H_{298.1^{\circ} \mathrm{K}}=-15.55 \pm 0.07 \mathrm{kcal} \text {. }
$$

By a similar treatment of the data for the heat of solution of $\mathrm{CaO}$ and $\mathrm{Ca}(\mathrm{OH})_{2}$ in the more dilute acid, there is obtained for the reaction expressed in eq 18 a value of $\Delta H_{298.11^{\circ} \mathrm{K}}$ equal to $-15.58 \pm 0.09 \mathrm{kcal}$. The average value of $\Delta H_{298.10 \mathrm{~K}}$ for this reaction, as determined by the heat-of-solution method, is therefore approximately $-15.57 \pm 0.08$ kcal.

The heat of hydration of $\mathrm{CaO}$ to $\mathrm{Ca}(\mathrm{OH})_{2}$ was also determined by the direct hydration of $\mathrm{CaO}$ in saturated lime water. The results of two experiments were $-15.38 \mathrm{kcal}$ and $-15.47 \mathrm{kcal}$, or an average of approximately $-15.43 \pm 0.09 \mathrm{kcal}$. The reaction of the direct hydration of $\mathrm{CaO}$ to $\mathrm{Ca}(\mathrm{OH})_{2}$ is expressed in the following equation:

$$
\begin{gathered}
\mathrm{CaO}(\mathrm{c})\left[\mathrm{CaCO}_{3} \text { ignited } 4 \mathrm{hr} \text { at } 1,075^{\circ} \mathrm{C}\right]+\mathrm{H}_{2} \mathrm{O}(\mathrm{liq}) \\
=\mathrm{Ca}(\mathrm{OH})_{2}(\mathrm{c})\left[\mathrm{Ca}(\mathrm{OH})_{2} \text { in saturated lime water }\right] ; \\
\Delta H_{298.1^{\circ} \mathrm{K}}=-15.43 \pm 0.09 \text { kcal. }
\end{gathered}
$$

\section{SUMMARY}

The heat evolved in the solution of $\mathrm{MgO}$ in hydrochloric acid was found to decrease as the temperature at which the $\mathrm{MgO}$ was prepared was increased. This is shown in the following equations where the values given are those of $\Delta H$, the increment in the heat content. The negative sign, therefore, indicates the evolution of heat.

$\mathrm{MgO}(\mathrm{c})\left[\mathrm{Mg}(\mathrm{OH})_{2}\right.$ dehydrated $2.5 \mathrm{hr}$ at $\left.450^{\circ} \mathrm{C}\right]+17,630 \mathrm{~g}$ of $2.085 \mathrm{M} \mathrm{HCl}=$ solution; $\Delta H_{298.10 \mathrm{~K}}=-36.67 \pm 0.07 \mathrm{kcal}$, and $\mathrm{MgO}(\mathrm{c})$ $\left[\mathrm{Mg}(\mathrm{OH})_{2}\right.$ dehydrated $2.5 \mathrm{hr}$ at $\left.1,425^{\circ} \mathrm{C}\right]+17,630 \mathrm{~g}$ of $2.085 \mathrm{M}$ $\mathrm{HCl}=$ solution; $\Delta H_{298.10 \mathrm{~K}}=-35.72 \pm 0.03 \mathrm{kcal}$.

The decrease in the heat evolved has been attributed to an increase in the particle size of the $\mathrm{MgO}$ as the temperature of ignition was increased. Since X-ray diffraction patterns were similar there appeared to be no change in crystalline form. The increase in particle 
size was indicated by a decrease in the rate of solution in the calorimeter and was verified by sedimentation experiments.

Heat values have also been obtained for the solution of $\mathrm{Mg}(\mathrm{OH})_{2}$, $\mathrm{CaO}$, and $\mathrm{Ca}(\mathrm{OH})_{2}$ in hydrochloric acid. The results are summarized in the equations which follow:

$\mathrm{Mg}(\mathrm{OH})_{2}(\mathrm{c})\left[\right.$ brucite] $+17,630 \mathrm{~g}$ of $2.085 \mathrm{M} \mathrm{HCl}-\mathrm{H}_{2} \mathrm{O}$ (liq) $=$ solution; $\Delta H_{298.1 \circ \mathrm{K}}=-26.64 \pm 0.01 \mathrm{kcal}$.

$\mathrm{Mg}(\mathrm{OH})_{2}(\mathrm{c})\left[\mathrm{MgO}\right.$ hydrated $2 \mathrm{hr}$ with saturated steam at $\left.177^{\circ} \mathrm{C}\right]$ $+17,630 \mathrm{~g}$ of $2.085 \mathrm{M} \mathrm{HCl}-\mathrm{H}_{2} \mathrm{O}($ liq $)=$ solution; $\Delta H_{298.10 \mathrm{~K}}=-26.88$ $\pm 0.03 \mathrm{kcal}$.

$\mathrm{CaO}(\mathrm{c})\left[\mathrm{CaCO}_{3}\right.$ ignited $4 \mathrm{hr}$ at $\left.1,075^{\circ} \mathrm{C}\right]+28,300 \mathrm{~g}$ of $2.085 \mathrm{M}$ $\mathrm{HCl}=$ solution; $\Delta H_{298.10 \mathrm{~K}}=-46.78 \pm 0.06 \mathrm{kcal}$.

$\mathrm{Ca}(\mathrm{OH})_{2}(\mathrm{c})\left[\mathrm{CaO}\right.$ hydrated $2 \mathrm{hr}$ with saturated steam at $\left.177^{\circ} \mathrm{C}\right]+$ $28,300 \mathrm{~g}$ of $2.085 M \mathrm{MCl}-\mathrm{H}_{2} \mathrm{O}$ (liq) $=$ solution; $\Delta H_{298.1{ }^{\circ} \mathrm{K}}=-31.23 \pm$ 0.04 kcal.

$\mathrm{CaO}(\mathrm{c})\left[\mathrm{CaCO}_{3}\right.$ ignited $4 \mathrm{hr}$ at $\left.1,075^{\circ} \mathrm{C}\right]+27,420 \mathrm{~g}$ of $0.277 \mathrm{M}$ $\mathrm{HCl}=$ solution; $\Delta H_{298.10^{\circ}}=-46.28 \pm 0.07 \mathrm{kcal}$.

$\mathrm{Ca}(\mathrm{OH})_{2}(\mathrm{c})\left[\mathrm{CaO}\right.$ hydrated $2 \mathrm{hr}$ with saturated steam at $\left.177^{\circ} \mathrm{C}\right]+$ $27,420 \mathrm{~g}$ of $0.277 \mathrm{M} \mathrm{HCl}-\mathrm{H}_{2} \mathrm{O}(\mathrm{liq})=$ solution; $\Delta H_{298.10 \mathrm{~K}}=-30.70 \pm$ 0.05 keal.

The heat of hydration of $\mathrm{MgO}$ to $\mathrm{Mg}(\mathrm{OH})_{2}$ may vary depending on characteristic properties of both the $\mathrm{MgO}$ and $\mathrm{Mg}(\mathrm{OH})_{2}$. Thus

$\mathrm{MgO}(\mathrm{c})\left[\mathrm{Mg}(\mathrm{OH})_{2}\right.$ dehydrated $2.5 \mathrm{hr}$ at $\left.450^{\circ} \mathrm{C}\right]+\mathrm{H}_{2} \mathrm{O}(\mathrm{liq})=$ $\mathrm{Mg}(\mathrm{OH})_{2}$ (c) [brucite]; $\Delta \dot{H}_{298.10 \mathrm{~K}}=-10.03 \pm 0.07 \mathrm{kcal}$, and

$\mathrm{MgO}(\mathrm{c})\left[\mathrm{Mg}(\mathrm{OH})_{2}\right.$ dehydrated $2.5 \mathrm{hr}$ at $\left.1,425^{\circ} \mathrm{C}\right]+\mathrm{H}_{2} \mathrm{O}(\mathrm{liq})=$ $\mathrm{Mg}(\mathrm{OH})_{2}\left[\mathrm{MgO}\right.$ hydrated $2 \mathrm{hr}$ with saturated steam at $\left.177^{\circ} \mathrm{C}\right]$; $\Delta H_{298.10 \mathrm{~K}}=-8.84 \pm 0.05 \mathrm{kcal}$.

The result of the determination by the heat-of-solution method of the heat of hydration of $\mathrm{CaO}$ to $\mathrm{Ca}(\mathrm{OH})_{2}$ is shown by the equation

$\mathrm{CaO}$ (c) $\left[\mathrm{CaCO}_{3}\right.$ ignited $4 \mathrm{hr}$ at $\left.1,075^{\circ} \mathrm{C}\right]+\mathrm{H}_{2} \mathrm{O}(\mathrm{liq})=\mathrm{Ca}(\mathrm{OH})_{2}(\mathrm{c})$ [CaO hydrated $2 \mathrm{hr}$ with saturated steam at $\left.177^{\circ} \mathrm{C}\right] ; \Delta H_{298.10 \mathrm{~K}}=$ $-15.57 \pm 0.08 \mathrm{kcal}$,

while the following equation shows the result obtained by direct hydration of $\mathrm{CaO}$ in saturated lime water:

$\mathrm{CaO}(\mathrm{c})\left[\mathrm{CaCO}_{3}\right.$ ignited $4 \mathrm{hr}$ at $\left.1,075^{\circ} \mathrm{C}\right]+\mathrm{H}_{2} \mathrm{O}(\mathrm{liq})=\mathrm{Ca}(\mathrm{OH})_{2}(\mathrm{c})$ $\left[\mathrm{Ca}(\mathrm{OH})_{2}\right.$ in saturated lime water]; $\Delta H_{298.1 \circ \mathrm{K}}=-15.43 \pm 0.09 \mathrm{kcal}$.

The authors acknowledge their indebtedness to Frederick D. Rossini for his many helpful suggestions, to Howard F. McMurdie for obtaining the X-ray diffraction patterns, and to Dana L. Bishop for his sedimentation experiments.

\section{REFERENCES}

[1] Wells and Taylor, J. Research NBS 19, 215 (1937) RP1022.

[2] Newman and Wells, J. Research NBS 20, 825 (1938) RP1107. Also Bureau of Reclamation Specification 566 for Boulder Dam Cement.

[3] Fricke, Schnabel, and Beck, Z. Elektrochem. 42, 881 (1936).

[4] Giauque and Archibald, J. Am. Chem. Soc. 59, 561 (1937).

[5] Bichowsky and Rossini, Thermochemistry of Chemical Substances, p. 113 and 117 (Reinhold Publishing Corporation, New York, N. Y., 1936).

[6] Rossini, BS J. Research 9, 679 (1932) RP499.

[7] Rossini, BS J. Research 4, 313 (1930) RP151; \%, 47 (1931) RP331.

[8] Int. Crit. Tables 11, 328 (1929).

[9] Gautier, Compt. rend. 128, 939 (1899). 
[10] Mixter, Am. J. Sci. 40, 23 (1915).

11] Roth and Chall, Z. Elektrochem. 34, 185 (1928).

[12] DeSchulten, Compt. rend. 101, 72 (1885).

[13] Thomsen, Thermochemische Untersuchungen 3, 247-248 (1883).

[14] Berthelot, Ann. chim. phys. [5] 4, 531 (1875)..

[15] Thorvaldson, Brown, and Peaker, J. Am. Chem. Soc. 52, 910 (1930).

[16] Schwiete and Hey, Z. anorg. Chem. 21\%, 396 (1934).

[17] Kohlschutter and Feitknecht, Helv. Chim. Acta 6, 337 (1923).

[18] Rossini, Chem. Rev. 18, 233 (1936).

Washington, May 20, 1938. 